\title{
Synthesis of Some Unique Carbamate Derivatives bearing 2-Furoyl-1-piperazine as Valuable Therapeutic Agents
}

\author{
Muhammad Athar Abbasi, ${ }^{1} *$ Ghulam Hussain, ${ }^{1}$ Aziz-ur-Rehman, ${ }^{1}$ \\ Sabahat Zahra Siddiqui, ${ }^{1}$ Syed Adnan Ali Shah, ${ }^{2,3}$ Muhammad Arif Lodhi, ${ }^{4}$ \\ Farman Ali Khan, ${ }^{4}$ Muhammad Ashraf, ${ }^{5}$ Qurat-ul-Ain, ${ }^{5}$ Irshad Ahmad, ${ }^{6}$ \\ Rabia Malik, ${ }^{6}$ Muhammad Shahid $^{7}$ and Zahid Mushtaq ${ }^{7}$ \\ ${ }^{1}$ Department of Chemistry, Government College University, Lahore-54000, Pakistan \\ ${ }^{2}$ Faculty of Pharmacy, Universiti Teknologi MARA, Puncak Alam Campus, 42300 Bandar Puncak Alam, \\ Selangor Darul Ehsan, Malaysia \\ ${ }^{3}$ Atta-ur-Rahman Institute for Natural Products Discovery (AuRIns), Level 9, FF3, Universiti Teknologi MARA, \\ Puncak Alam Campus, 42300 Bandar Puncak Alam, Selangor Darul Ehsan, Malaysia \\ ${ }^{4}$ Department of Biochemistry, Abdul Wali Khan University, Mardan-23200, Pakistan \\ ${ }^{5}$ Department of Chemistry, The Islamia University of Bahawalpur, Bahawalpur-63100, Pakistan \\ ${ }^{6}$ Department of Pharmacy, The Islamia University of Bahawalpur, Bahawalpur-63100, Pakistan \\ ${ }^{7}$ Department of Biochemistry, University of Agriculture, Faisalabad-38040, Pakistan \\ *Corresponding author: E-mail: atrabbasi@yahoo.com; abbasi@gcu.edu.pk \\ tel: (+92)-42-111000010, ext. 266.
}

Received: 12-10-2016

\begin{abstract}
The aim of the research work was to synthesize different biologically active carbamate derivatives bearing 2-furoyl-1piperazine and having modest toxicity. The synthesis was completed as a multiple sequence. The structural confirmation of all the synthesized compounds was obtained by EI-MS, IR and ${ }^{1} \mathrm{H}-\mathrm{NMR}$ spectral data. The enzyme inhibition and antibacterial potential of the synthesized compounds was evaluated. To find the utility of the prepared compounds as possible therapeutic agents their cytotoxicity was also checked. All the compounds were active against acetylcholinesterase enzyme, especially $\mathbf{1 2}$ and $\mathbf{1 4}$ showed very good inhibitory potential relative to Eserine, a reference standard. Almost all the compounds showed good activities against both Gram-positive and Gram-negative bacterial strains.
\end{abstract}

Keywords: 2-Furoyl-1-piperazine; ${ }^{1} \mathrm{H}-\mathrm{NMR}$; Acetylcholinesterase; Antimicrobial activity; Hemolytic activity

\section{Introduction}

Heterocyclic compounds are cyclic compounds having hetero atoms e.g, $\mathrm{N}, \mathrm{O}$ or $\mathrm{S}$, having diverse medicinal importance. ${ }^{1}$ Piperazine is a medicinally important heterocyclic nucleus which consists of a six membered ring containing two nitrogen atoms at the positions 1 and 4 in the ring. The piperazine has been classified as a privileged structure and is frequently found in biologically active compounds across a number of different therapeutic areas $^{2}$ which encompass anti-microbial, anti-tubercular, anti-psychotic, anti-convulsant, anti-depressant, anti-inflammatory, cytotoxic, anti-malarial, anti-arrhythmic, antioxidant and anti-viral activities. ${ }^{3,4}$ 
Carbamates are derivatives of carbamic acid $\left(\mathrm{NH}_{2} \mathrm{COOH}\right)$. A carbamate group, carbamate group, carbamate ester and carbamic acids functional groups are unified structurally and often are interconverted chemically. Carbamate esters are also called urethanes. Although most of the literature is concerned with organic carbamates, yet, the inorganic salt ammonium carbamate is produced on a large scale from ammonia and carbon dioxide. The amino groups of the lysine residues in urease and phosphotriesterase also attribute carbamate. The carbamate resulting from aminoimidazole is an intermediate in the biosynthesis of . Carbamoyl phosphate is generated from carboxyphosphate rather than $\mathrm{CO}_{2}{ }^{5}$ The carbamate insecticides featuring the carbamate ester functional group, e.g, Aldicarb, Carbofuran, Carbaryl (Fig. 1) etc., encompass this group.

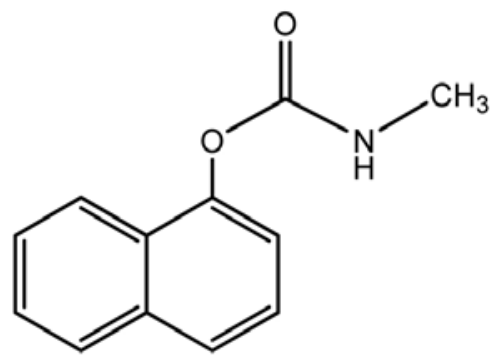

Fig. 1. Carbaryl (insecticide carbamate)

The organophosphate pesticides also hinder this enzyme, although irreversibly, and originate a more severe form of cholinergic poisoning. ${ }^{6}$ Iodopropynyl butylcarbamate is a wood and paint preservative and used in the cosmetics $^{7}$. Urethane (ethylcarbamate) was once produced commercially in the United States as an anti-neoplastic agent and for other medicinal purposes. It was found toxic and largely ineffective and is now seldom used as a veterinary medicine. ${ }^{8}$

$\alpha$-Glucosidase comprises class of hydrolase enzymes, located in the brush border surface membrane of small intestinal cells. ${ }^{9}$ The vital function of $\alpha$-glucosidase is to hydrolyze the 1,4 glycosidic linkage from the non reducing end of the $\alpha$-glucosides, substrates to produce $\alpha$ D-glucose and other monosaccharide which are operated as carbon and energy source. ${ }^{10}$ For oral anti-diabetic drugs for patients with type-2 Diabetes mellitus $\alpha$-glucosidase inhibitors compounds are used. Postprandial hyperglycemia has a role in the growth of type- 2 diabetes and problems associated with disease such as nephropathy and macroangipathy etc. ${ }^{11}$ The inhibitors of enzyme can hinder the release of D-glucose of oligosaccharides and disaccharides beginning dietary complex carbohydrates and holdup glucose absorption, resulting in compact postprandial hyperglycemia. ${ }^{12}$

Acetyl and butyrylcholinesterases (AChE/BChE) comprise a family of serine hydrolases. The different spe- cificities for substrates and inhibitors for these enzymes are caused by the differences in amino acid residues of the active sites of AChE and BChE. The enzyme scheme is liable for the termination of acetylcholine at cholinergic synapses. These are main components of cholinergic brain synapses and neuromuscular junctions. The chief function of $\mathrm{AChE}$ and $\mathrm{BChE}$ is to catalyze the hydrolysis of the neurotransmitter acetylcholine. ${ }^{13,14}$ It has been found that $\mathrm{BChE}$ is present in appreciably higher quantities in Alzheimer's plaques in the normal age related to non dementia of brains. Cholinesterase inhibitors increase the amount of acetylcholine offered for neuromuscular and neuronal transmission through their reversible or irreversible inhibitory activity ${ }^{15}$ Hence, the search for new cholinesterase inhibitors is consider an important strategy to introduce new drug candidates for the treatment of Alzheimer's disease and other related diseases. ${ }^{16}$ Different microbes have been found to be involved in many diseases ${ }^{17-22}$ and some of them are included in the current study. So, in continuation of our previous work on carbamates, ${ }^{23-25}$ hereby we report the synthesis of some unique carbamates having amalgamation with 2-furoylpiperazine moiety, which might find their utility as potential and safe thereapeutic agents.

\section{Results and Discussion}

The aim of the present research work was to synthesize new biologically active compounds with low toxicity. Indeed, the current need is to introduce pharmacologically active drugs to help in pharmacy against the increasing resistance of microorganisms.

\section{1. Chemistry}

In the present research work, different carbamate derivatives bearing 2-furoyl-1-piperazine were synthesized in a series of steps by a reported method ${ }^{26}$ as shown in Scheme 1 and then all the derivatives were screened for enzyme inhibition, antimicrobial and hemolytic activities. The structural analysis of one of the compounds is discussed here in detail for the benefit of the reader. The molecule $\mathbf{1 6}$ was synthesized as an off-white amorphous solid having melting point $80-92{ }^{\circ} \mathrm{C}$ and molecular formula $\mathrm{C}_{19} \mathrm{H}_{20} \mathrm{Br}_{3} \mathrm{~N}_{3} \mathrm{O}_{4}$, which was confirmed by EI-MS having $[\mathrm{M}]^{+}$peak at $\mathrm{m} / \mathrm{z}, 591$ and by the number of protons in its ${ }^{1} \mathrm{H}-\mathrm{NMR}$ spectrum. The $\mathrm{CHN}$ analysis data of this molecule also supported the assignement of its molecular formula. Its structure was corroborated by the distinct ion peak at $\mathrm{m} / z, 93$ related to $N$-furoyl group and another at $\mathrm{m} / \mathrm{z} 332$ for $O$-(2,6-dibromophenyl)- $N$-(allyl)carbamate part. The suggested mass fragmentation pattern is given in Fig. 2. In IR spectrum of 16, characteristic peaks appeared at $v 3406(\mathrm{~N}-\mathrm{H}), 3086(\mathrm{Ar} \mathrm{C}-\mathrm{H}), 2882(\mathrm{R} \mathrm{C}-\mathrm{H}), 1657$ $(\mathrm{C}=\mathrm{O}), 1582(\mathrm{Ar} \mathrm{C}=\mathrm{C}), 1497(\mathrm{~N}=\mathrm{O}), 1197(\mathrm{C}-\mathrm{O}-\mathrm{C})$, $1110(\mathrm{C}-\mathrm{N}-\mathrm{C}), 847(\mathrm{C}-\mathrm{N})$ and $548 \mathrm{~cm}^{-1}(\mathrm{C}-\mathrm{Br})$ which al- 
together confirmed the presence of the carbamate group and 2-furoyl-1-piperazine ring. In the aromatic region of ${ }^{1} \mathrm{H}-\mathrm{NMR}$ spectrum, a two-proton singlet appeared at $\delta$ 7.67 (s, 2H, H-3 and H-5) which is typical for a 2,4,6tribromophenyl moiety attached via an oxygen atom. The other three peaks in the aromatic region at $\delta 7.49$ (brs, $1 \mathrm{H}$, H-5"'), 7.04 (d, $J=4.1 \mathrm{~Hz}, 1 \mathrm{H}, \mathrm{H}-3$ "') and 6.49 (dd, $J=$ 4.0, $2.0 \mathrm{~Hz}, 1 \mathrm{H}, \mathrm{H}-4$ "') are characteristic for a 2-furyl ring. Moreover, a singlet $\delta 5.19$ represents $\mathrm{NH}$ of the carbamate group, while the 1,4-disubstituted piperazine ring was deduced through two broad singlets in aliphatic region, and each broad singlet representing two symmetrical methylene groups. These two singlets resonated at $\delta$ $3.94(4 \mathrm{H})$ and $\delta 3.47(4 \mathrm{H})$. The former was assigned to symmetrical $\mathrm{CH}_{2}-3$ " and $\mathrm{CH}_{2}-5$ " while latter was assigned to symmetrical $\mathrm{CH}_{2}-2$ " and $\mathrm{CH}_{2}-6$ " in the piperazine entity. Similary, the presence of a central 1,3-disubstitued propyl group was ascertained by the signals resonating at $\delta 4.12\left(\mathrm{t}, J=6.6 \mathrm{~Hz}, 2 \mathrm{H}, \mathrm{CH}_{2}-1^{\prime}\right), 3.61-3.57(\mathrm{~m}, 2 \mathrm{H}$,
$\mathrm{CH}_{2}-3^{\prime}$ ) and 2.10 (quintet, $J=6.8 \mathrm{~Hz}, 2 \mathrm{H}, \mathrm{CH}_{2}-2^{\prime}$ ). The ${ }^{1} \mathrm{H}-\mathrm{NMR}$ spectrum of this molecule is shown in Fig. 3. So, on the basis of aforementioned spectral evidences, the structure of $\mathbf{1 6}$ was confirmed as 2,4,6-tribromophenyl 3[4-(2-furoyl)-1-piperazinyl]propylcarbamate. All the synthesized carbamate derivatives bearing 2-furoyl-1-piperazine were characterized by IR, ${ }^{1} \mathrm{H}-\mathrm{NMR}$ and EI-MS spectral analysis in a similar way.

\section{2. Biological Activities (in vitro)}

\section{2. 1. Enzyme Inhibition Activity}

The synthesized compounds exhibited variable inhibitory potentials against $\alpha$-glucosidase, acetylcholinesterase and butyrylcholinesterase as evident from their $\mathrm{IC}_{50}$ values presented in Table 1. Only two compounds, 2,4,6tribromophenyl 2-[4-(2-furoyl)-1-piperazinyl]ethylcarbamate (9) and 2,4,6-tribromophenyl 3-[4-(2-furoyl)-1-piperazinyl]propylcarbamate (16) showed weak inhibitory po-

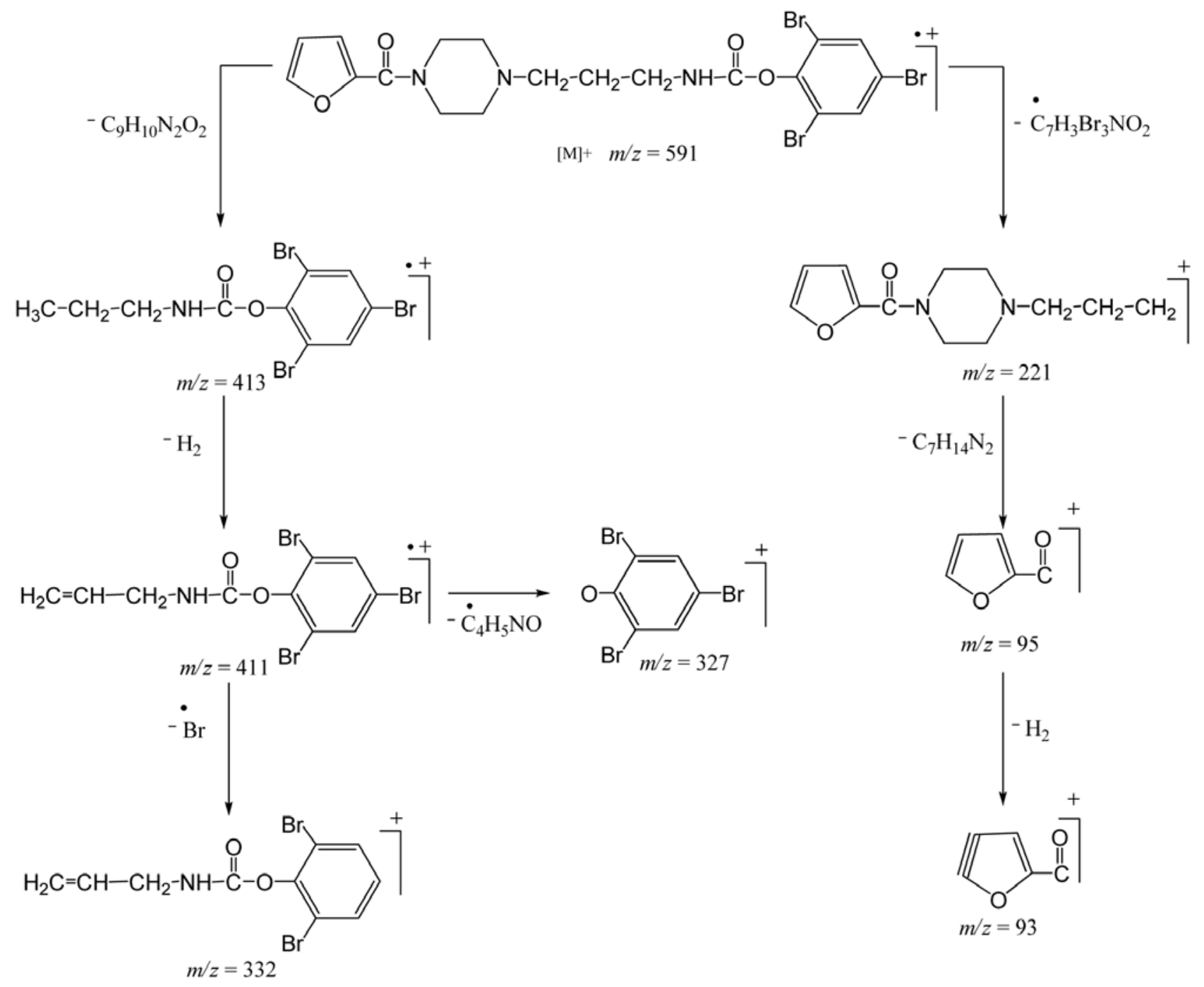

Fig. 2. Suggested mass fragmentation pattern of 2,4,6-tribromophenyl 3-[4-(2-furoyl)-1-piperazinyl]propylcarbamate (16). 


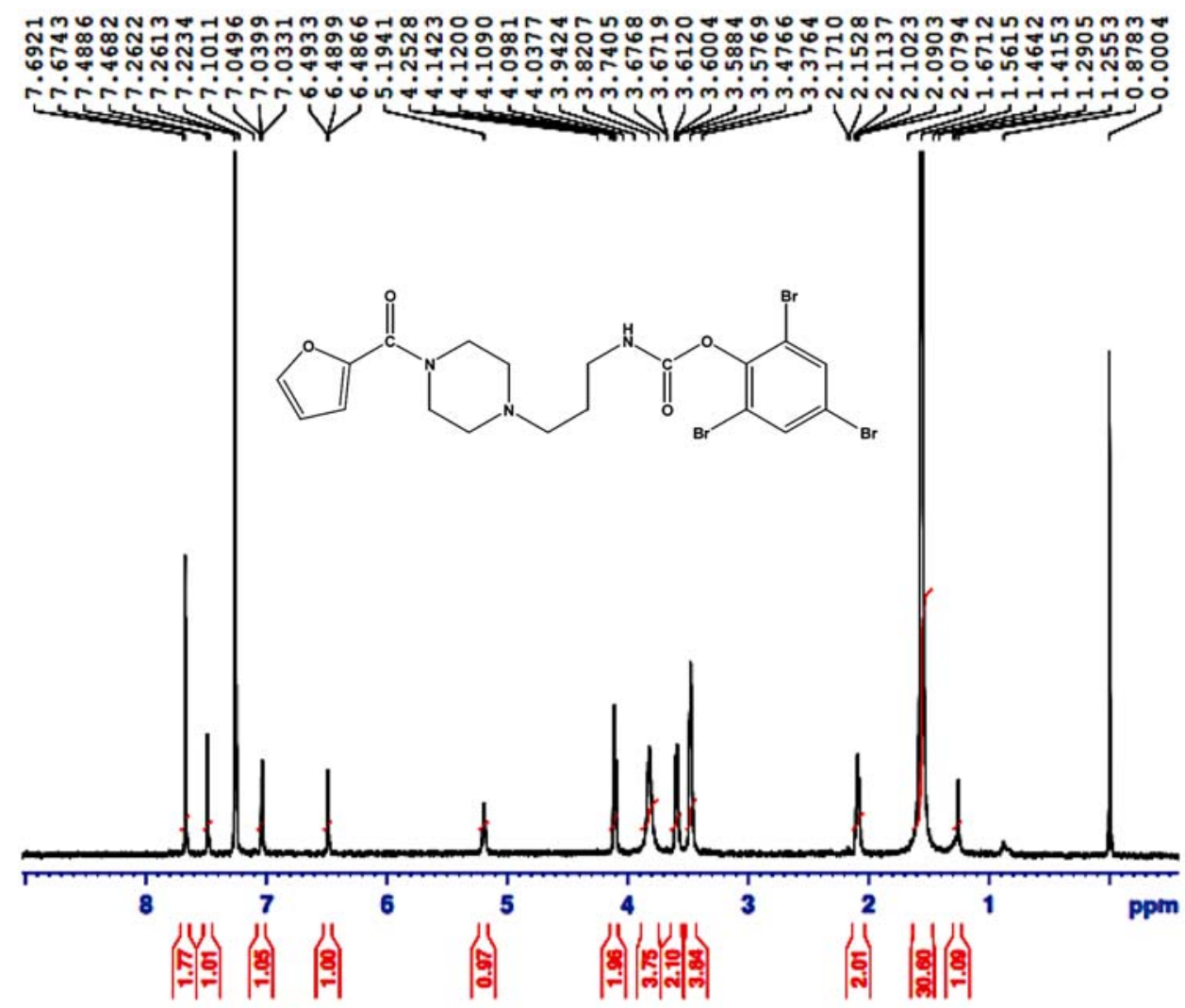

Fig. 3. ${ }^{1} \mathrm{H}-\mathrm{NMR}$ spectrum of 2,4,6-tribromophenyl-3-[4-(2-furoyl)-1-piperazinyl]propylcarbamate (16)

Table 1. Bioactivity studies of different carbamate derivatives bearing 2-furoyl-1-piperazine

\begin{tabular}{|c|c|c|c|c|c|c|}
\hline \multirow{2}{*}{ Compound } & \multicolumn{2}{|c|}{$\alpha$-Glucosidase } & \multicolumn{2}{|c|}{ AchE } & \multicolumn{2}{|c|}{ BChE } \\
\hline & $\%$ Inhibition & $\mathrm{IC}_{50}(\mu \mathrm{M})$ & $\%$ Inhibition & $\mathrm{IC}_{50}(\mu \mathrm{M})$ & $\%$ Inhibition & $\mathrm{IC}_{50}(\mu \mathrm{M})$ \\
\hline 5 & $25.45 \pm 0.31$ & - & $78.59 \pm 0.23$ & $34.62 \pm 0.19$ & $28.35 \pm 0.16$ & - \\
\hline 7 & - & - & $81.35 \pm 0.96$ & $456.45 \pm 0.29$ & - & - \\
\hline 9 & $94.32 \pm 0.28$ & $345.16 \pm 0.60$ & $77.15 \pm 0.18$ & $32.51 \pm 0.03$ & $48.16 \pm 0.27$ & - \\
\hline 12 & $32.34 \pm 0.26$ & - & $81.63 \pm 0.15$ & $18.91 \pm 0.04$ & $55.71 \pm 0.24$ & $361.27 \pm 0.13$ \\
\hline 14 & $27.67 \pm 0.45$ & - & $82.45 \pm 0.11$ & $23.22 \pm 0.05$ & $33.26 \pm 0.25$ & - \\
\hline 16 & $85.54 \pm 0.32$ & $422.61 \pm 0.30$ & $81.76 \pm 0.12$ & $24.71 \pm 0.07$ & $43.45 \pm 0.21$ & - \\
\hline Control & $92.23 \pm 0.14^{a}$ & $38.25 \pm 0.12^{a}$ & $91.27 \pm 1.17^{b}$ & $0.04 \pm 0.0001^{b}$ & $82.82 \pm 1.09^{b}$ & $0.85 \pm 0.0001^{b}$ \\
\hline
\end{tabular}

NOTE: All compounds were dissolved in methanol and experiments were performed in triplicate (mean $\pm \mathrm{SEM}, n=3$ ). $\mathrm{a}=$ Acarbose, $\mathrm{b}=$ Eserine, $\mathrm{AChE}=$ Acetylcholinesterase, $\mathrm{BChE}=$ Butyrylcholinesterase

tential against $\alpha$-glucosidase, having $\mathrm{IC}_{50}$ value of 345.16 $\pm 0.16 \mu \mathrm{M}$ and $422.61 \pm 0.13 \mu \mathrm{M}$, respectively, relative to Acarbose, used as a reference standard having $\mathrm{IC}_{50}$ value of $38.25 \pm 0.12 \mu \mathrm{M}$. This inhibitory potential might be attributed to the presence of 2,4,6-tribromophenyl group in both molecules. All the molecules were active against acetylcholinesterase enzyme but among all molecules phenyl 3-[4-(2-furoyl)-1-piperazinyl]propylcarbamate (12) exhibited the best inhibitory potential against this enzyme with $\mathrm{IC}_{50}$ value of $18.91 \pm 0.04 \mu \mathrm{M}$, relative to Eserine, a reference standard having $\mathrm{IC}_{50}$ value of $0.04 \pm$ $0.0001 \mu \mathrm{M}$. This enhanced inhibitory potential of $\mathbf{1 2}$ can be a result of its unique skeleton as a whole. Moreover, this was the only molecule which showed some inhibitory tendency against butyrylcholinesterase enzyme with $\mathrm{IC}_{50}$ value of $361.27 \pm 0.13 \mu \mathrm{M}$. In the future some modified derivatives of this molecule are suggested to show much closer $\mathrm{IC}_{50}$ value to the standard Eserine.

\section{2. 2. Antibacterial Activity}

All the synthesized molecules were screened against Gram-positive and Gram-negative bacteria, and were found to be excellent-to-good antibacterial agents. The re- 
sults are shown as MIC values in Table 2. Among the synthesized carbamates, $\mathbf{1 6}$ showed the lowest MIC value $(8.96 \pm 0.49 \mu \mathrm{M})$ against $S$. typhi credibly because of the presence of 2,4,6-tribromophenyl group. In the case of $E$. coli, carbamate 14 showed the lowest MIC value (9.95 \pm $0.48 \mu \mathrm{M})$ probably due to the presence of 2,4,6-trinitrophenyl group. Against $P$. aeruginosa and $B$. subtilis, 16 and 9 exhibited excellent antibacterial potential with MIC values $9.27 \pm 0.16 \mu \mathrm{M}$ and $9.43 \pm 0.85 \mu \mathrm{M}$, respectively, predominantly because of the presence of 2,4,6-trinitrophenyl group and 2,4,6-tribromophenyl group, respectively, in these molecules. Similarly, the carbamate $\mathbf{1 6}$ also rendered a great antibacterial activity against $S$. aureus with MIC value $16.87 \pm 0.41 \mu \mathrm{M}$. Amongst the synthesized compounds, $\mathbf{5}$ and $\mathbf{1 6}$ showed MIC values against all the bacterial strains while compound $\mathbf{1 6}$ showed the excellent MIC value in the following order towards all bacterial strains: S. typhi $>$ P. aeroginosa $>$ B. subtilis $>$ E. coli $>$ $S$. aureus, probably due to the presence of 2,4,6-tribromophenyl moiety. In general, we can say that most of the carbamates possessed very good antibacterial activities against both Gram-positive and Gram-negative bacterial strains and hence these molecules might lead to the discovery of very potent antibacterial agents in future.

\section{2. 3. Hemolytic Activity}

Most of the molecules exhibited very modest cytotoxicity values, except 14 (72.38\%), yet it was lower than the positive control (Triton-X-100). The lowest activity was shown by the molecule $\mathbf{1 6}$ (9.20\%), although it was a little higher than the negative controls (PBS). So it can be concluded that these molecules might be further tested for their therapeutic applications in the drug designing program because of their moderate toxicity, as shown in Table 2.

\section{2. 4. Computational Docking}

In order to get an insight about the validity of accuracy, the co-crystallized ligands of the following enzymes

Table 2. Antibacterial activity (MIC) and hemolytic activity of different carbamate derivatives bearing 2-furoyl-1-piperazine

\begin{tabular}{|c|c|c|c|c|c|c|}
\hline \multirow[t]{2}{*}{ Compound } & \multicolumn{5}{|c|}{ MIC $(\mu \mathrm{M})$} & \multirow{2}{*}{$\begin{array}{c}\text { Hemolytic } \\
\text { activity } \\
\%\end{array}$} \\
\hline & S. typhi (-) & E. $\operatorname{coli}(-)$ & P.aeroginosa (-) & B. subtilis (+) & S. aureus (+) & \\
\hline 5 & $9.08 \pm 0.50$ & $17.43 \pm 0.61$ & $19.87 \pm 0.51$ & $10.85 \pm 0.14$ & $19.98 \pm 0.58$ & 24.26 \\
\hline 7 & $9.14 \pm 0.15$ & $16.98 \pm 0.75$ & $18.34 \pm 0.92$ & $10.78 \pm 0.93$ & - & 15.94 \\
\hline 9 & $9.89 \pm 0.17$ & $14.43 \pm 0.05$ & $9.87 \pm 0.43$ & $9.43 \pm 0.85$ & - & 12.10 \\
\hline 12 & $9.88 \pm 0.75$ & $15.64 \pm 0.32$ & $17.67 \pm 0.34$ & $11.76 \pm 0.54$ & - & 53.13 \\
\hline 14 & $9.78 \pm 0.90$ & $9.95 \pm 0.48$ & $17.78 \pm 0.33$ & $16.49 \pm 0.27$ & - & 72.38 \\
\hline 16 & $8.96 \pm 0.49$ & $10.64 \pm 0.58$ & $9.27 \pm 0.16$ & $9.78 \pm 0.62$ & $16.87 \pm 0.41$ & 9.20 \\
\hline Ciprofloxacin & $7.45 \pm 0.58$ & $7.16 \pm 0.58$ & $7.14 \pm 0.18$ & $7.29 \pm 0.90$ & $7.80 \pm 0.19$ & \\
\hline PBS & & & & & & 0.09 \\
\hline Triton & & & & & & 100 \\
\hline
\end{tabular}

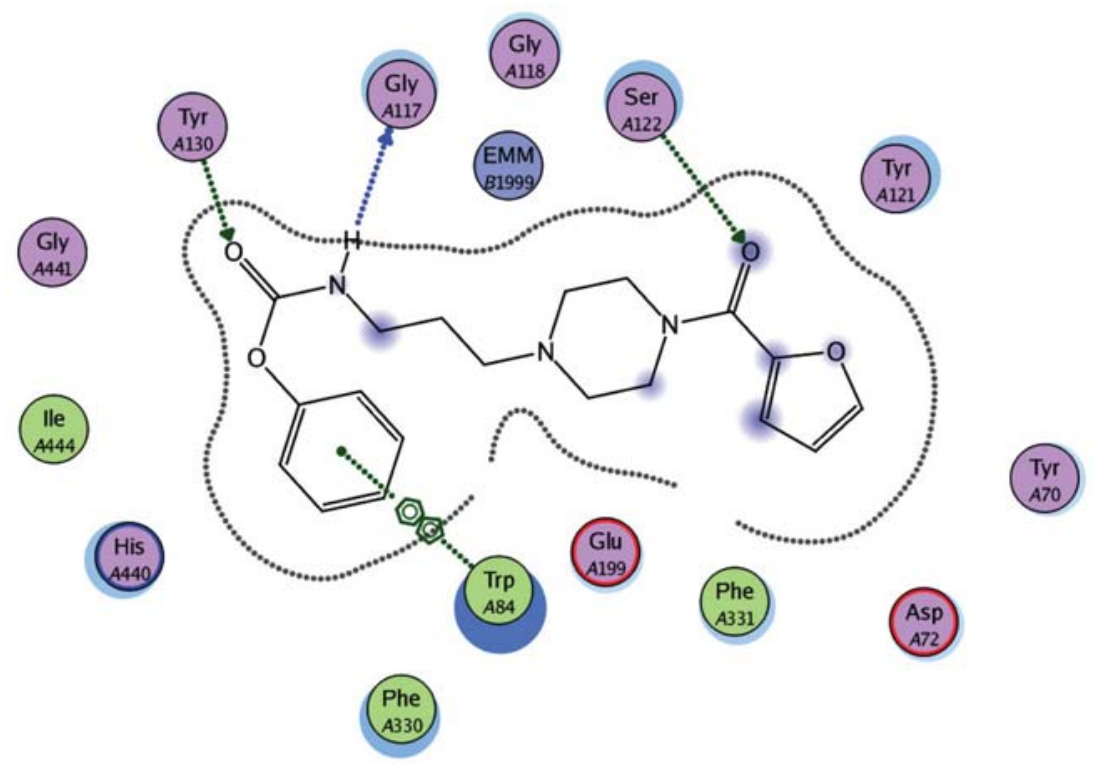

Fig. 4. 2D interacted image of phenyl 3-[4-(2-furoyl)-1-piperazinyl]propylcarbamate (12) against acetylcholinestrase. 


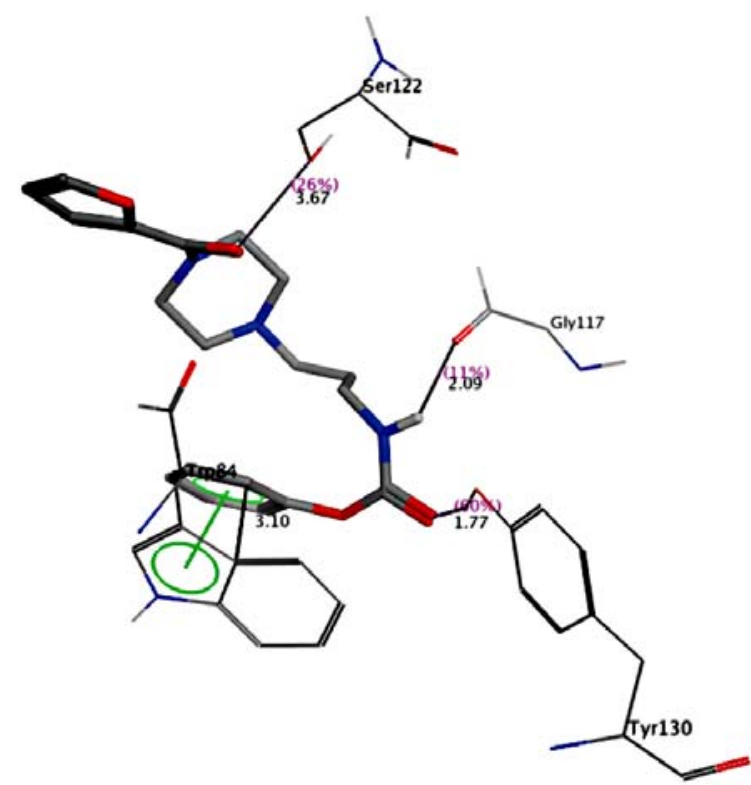

Fig. 5. 3D interacted image of phenyl 3-[4-(2-furoyl)-1-piperazinyl]propylcarbamate (12) against acetylcholinestrase. were extracted and then re-docked into the binding pockets of the receptors. In all these cases, RMSD values between docked and co-crystallized ligands were less than 2 $\dot{A}$ which indicates the reliability of docking method and thus showing that our protocol can be used for further studies. Almost all the synthesized derivatives were computationally docked against $\alpha$-glucosidase, $\mathrm{AChE}$ and $\mathrm{BChE}$ to explore the binding modes of all the ligands. The carbamate 12 was docked against acetylcholinesterase. There were observed four prominent interactions between $\mathbf{1 2}$ and active residues of the protein. First strongest side chain donor interaction was found between TyrA130 and carbonyl oxygen giving a distance of $1.77 \AA$, second between SerA122 and another carbonyl oxygen with the distance of $3.67 \AA$. Third strong back bone donor interaction was established between GlyA117 and amide proton of the ligand with a distance of $2.09 \AA$. Similarly the last hydrophobic interaction of a distance of $3.10 \AA$ was found between TrpA81 and phenyl ring of the ligand as shown in Fig. 4 and 5. From the same compound $\mathbf{1 2}$ protein docked complex of butyrylcholinesterase, this interacted weakly

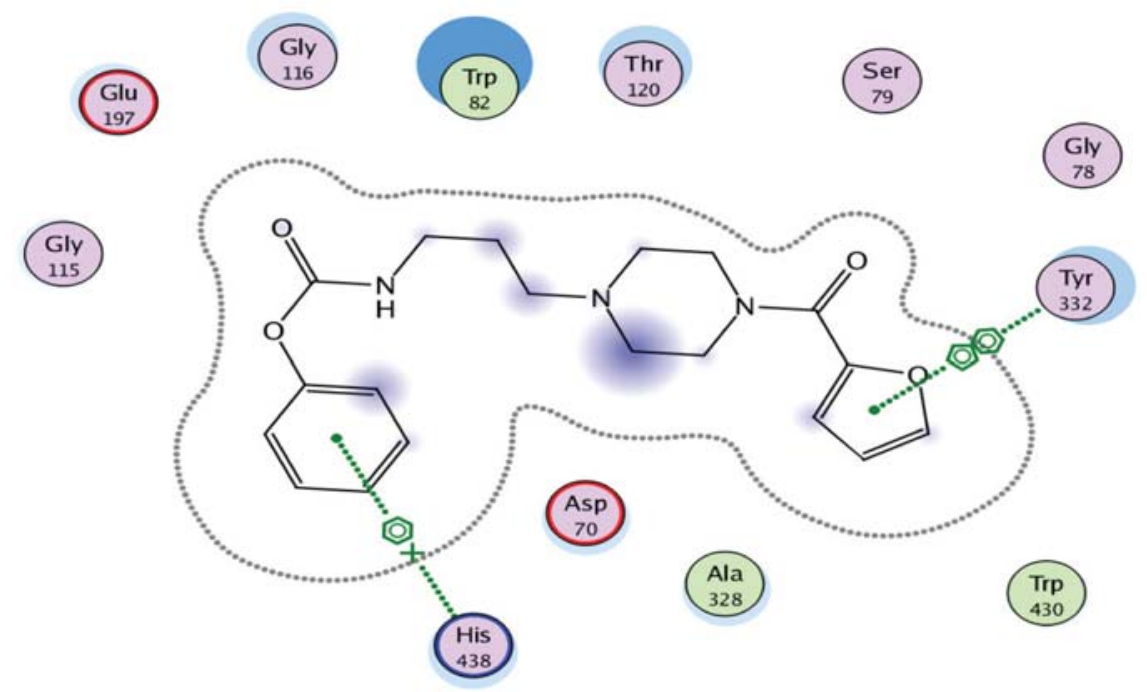

Fig. 6. 2D interacted image of phenyl 3-[4-(2-furoyl)-1-piperazinyl]propylcarbamate (12) against butyrylcholinesterase.

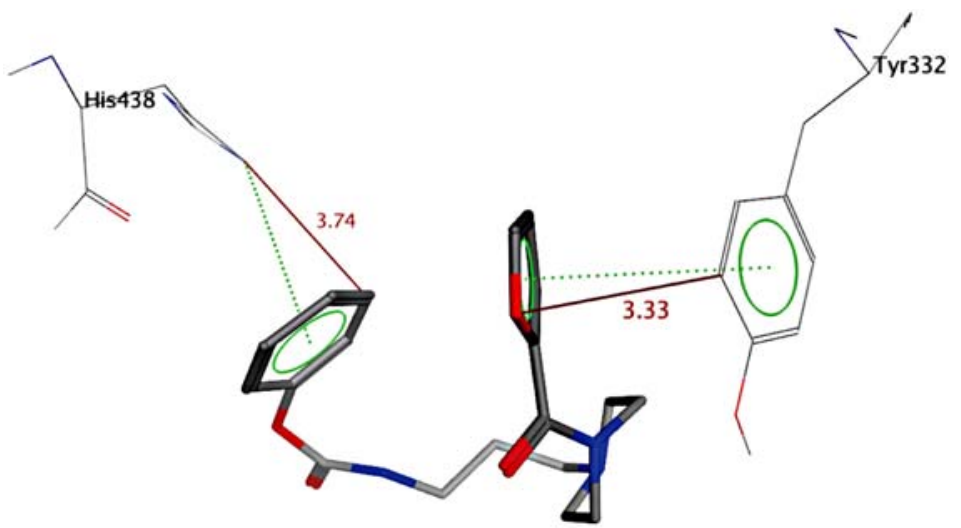

Fig. 7. 3D interacted image of phenyl 3-[4-(2-furoyl)-1-piperazinyl]propylcarbamate (12) against butyrylcholinesterase. 
with Tyr332 and His438 amino acid residues. Tyr332 displayed arene-arene interaction with furoyl ring with the distance of $3.36 \AA$, while His438 displayed arene cation interaction with phenyl ring with a distance of $3.74 \AA$ as it is shown in Fig. 6 and 7.

\section{Experimental}

\section{1. General}

Chemicals and solvents of analytical grade were purchased from Sigma Aldrich and Alfa Aesar (Germany). By using an open capillary tube method, melting points were determined on Griffin and George apparatus and are uncorrected. By using thin layer chromatography (TLC) in various percentages of ethyl acetate and $n$-hexane as mobile phase, initial purity of compounds was detected at $254 \mathrm{~nm}$. IR peaks were recorded on a Jasco-320-A spectrometer by using a $\mathrm{KBr}$ pellet method. ${ }^{1} \mathrm{H}-\mathrm{NMR}$ signals were recorded at $500 \mathrm{MHz}$ in $\mathrm{CDCl}_{3}$ using Bruker spectrometers. EI-MS signals were recorded by utilizing a JMS-HX-110 spectrometer.

\section{2. Synthesis of Phenyl (N-substituted) carbamates 3 and 11}

2-Chloroethylamine (2-chloro-1-ethanamine; $2 ; 0.1$ mol) and 3-bromopropylamine $(\mathbf{1 0} ; 0.1 \mathrm{~mol})$ were taken separately in two iodine flasks, each containing $10 \mathrm{~mL} \mathrm{di-}$ stilled water. The $\mathrm{pH}$ of the solution was maintained at 9-10 by $10 \%$ aqueous $\mathrm{Na}_{2} \mathrm{CO}_{3}$ followed by the addition of phenyl carbonochloridic acid (phenylchloroformate; 1; $0.1 \mathrm{~mol}$,) in equimolar ratios in each flask along with vigorous shaking. The reaction mixture in each case was stirred at room temperature for 3-4 h. Progress of the reaction was confirmed by TLC ( $n$-hexane : EtOAc; 70:30), visualized by UV lamp. Phenyl 2-chloroethylcarbamate (3) and phenyl 3-bromopropylcarbamate (11) were collected as white precipitates by filtration. These were washed with distilled water and dried to acquire pure compounds.

\section{3. Nitration of Phenyl ( $N$-substituted) carbamates Yielding 6 and 13}

Phenyl 2-chloroethylcarbamate $(\mathbf{3} ; 0.1 \mathrm{~mol})$ and phenyl 3-bromopropylcarbamate (11; $0.1 \mathrm{~mol})$ were taken separately in two $50 \mathrm{~mL}$ round bottom flasks. 5-10 mL concentrated $\mathrm{H}_{2} \mathrm{SO}_{4}$ was added in each flask to dissolve the respective compound. Each mixture was stirred for 15-20 min at room temperature and then equimolar amount of nitric acid was added to each mixture dropwise at $10{ }^{\circ} \mathrm{C}$. Then each reaction mixture was stirred for $4 \mathrm{~h}$ and monitored by TLC. On reaction completion, ice cold water was added to the reaction flasks to produce the precipitates which were collected by filtration, washed with distilled water and dried to afford the nitrated compounds $\mathbf{6}$ and 13, separately.

\section{4. Bromination of Phenyl ( $N$-substituted) carbamates Yielding 8 and 15}

Phenyl 2-chloroethylcarbamate $(\mathbf{3} ; 0.1 \mathrm{~mol})$ and phenyl 3-bromopropylcarbamate $(\mathbf{1 1} ; 0.1 \mathrm{~mol})$ were taken separately in two $50 \mathrm{ml}$ round bottomed flasks and were dissolved in glacial acetic acid $(5-10 \mathrm{~mL})$. Liquid bromine was added slowly in equimolar amount to eack flask. The reaction mixture in each case was stirred at room temperature and monitored with TLC for the completion of the reaction. Distilled water was added to each reaction flask to quench the reaction. Precipitated products were filtered, washed with distilled water and dried to obtain pure brominated compounds $\mathbf{8}$ and $\mathbf{1 5}$, separately.

\section{5. Synthesis of Different Carbamate Derivatives Bearing 2-Furoyl-1 -piperazine Moiety}

2-Furoyl-1-piperazine $(4 ; 4.5 \mathrm{mmol})$ dissolved in 20-30 mL acetonitrile was taken in a $100 \mathrm{~mL}$ round bottom flask, solid $\mathrm{K}_{2} \mathrm{CO}_{3}(13.5 \mathrm{mmol})$ was added and the reaction mixture was refluxed for half an hour followed by the addition of respective carbamates $(\mathbf{3}, \mathbf{6}, \mathbf{8}, \mathbf{1 1}, \mathbf{1 3}$ or 15; one in each case) in equimolar ratio. The mixture was refluxed for 4-5 h. TLC was carried out to check the reaction completion (20\% ethyl acetate: $80 \% n$-hexane). Distilled water was added to the reaction mixture to acquire the respective precipitates. On completion, 1-2 drops of aqueous $\mathrm{NaOH}$ were added to the reaction mixture. Precipitates were filtered, washed and dried to obtain the respective carbamates $5,7,9,12,14$ or 16 (one in each case) bearing 2-furoyl-1-piperazine.

\section{5. 1. Phenyl 2-[4-(2-furoyl)-1-piperazinyl] ethylcarbamate (5)}

Sticky brown liquid; Yield: 90\%; Mol. F.: $\mathrm{C}_{18} \mathrm{H}_{21} \mathrm{~N}_{3} \mathrm{O}_{4}$; Mol. Mass.: $343 \mathrm{~g} / \mathrm{mol}$; IR $\left(\mathrm{KBr}, \mathrm{cm}^{-1}\right) v_{\text {max }}$ : $3406(\mathrm{~N}-\mathrm{H}), 3086(\mathrm{Ar} \mathrm{C}-\mathrm{H}), 2882(\mathrm{R} \mathrm{C}-\mathrm{H}), 1657(\mathrm{C}=\mathrm{O})$, $1582(\mathrm{Ar} \mathrm{C}=\mathrm{C}), 1498(\mathrm{~N}=\mathrm{O}), 1197(\mathrm{C}-\mathrm{O}-\mathrm{C}), 1110$ (C-N-C), $853(\mathrm{C}-\mathrm{N}) ;{ }^{1} \mathrm{H}-\mathrm{NMR}\left(500 \mathrm{MHz}, \mathrm{CDCl}_{3}, \mathrm{ppm}\right)$ : $\delta 7.49$ (brs, $1 \mathrm{H}, \mathrm{H}-5$ "'), 7.45 (brt, $J=7.2 \mathrm{~Hz}, 2 \mathrm{H}, \mathrm{H}-3$ and $\mathrm{H}-5$ ), 7.15 (brt, $J=7.3 \mathrm{~Hz}, 1 \mathrm{H}, \mathrm{H}-4$ ), 7.07 (brd, $J=7.7$ $\mathrm{Hz}, 2 \mathrm{H}, \mathrm{H}-2$ and $\mathrm{H}-6), 7.01$ (d, $J=4.1 \mathrm{~Hz}, 1 \mathrm{H}, \mathrm{H}-3$ '"'), 6.50 (dd, $J=1.9,3.2 \mathrm{~Hz}, 1 \mathrm{H}, \mathrm{H}-4$ "”), 5.19 (s, 1H, NH), 3.84 (brs, $4 \mathrm{H}, \mathrm{CH}_{2}-3$ " and $\mathrm{CH}_{2}-5$ "), 3.39 (t, $J=6.2 \mathrm{~Hz}$, $2 \mathrm{H}, \mathrm{CH}_{2}-1^{\prime}$ ), 2.56 (brt, $J=6.0 \mathrm{~Hz}, 4 \mathrm{H}, \mathrm{CH}_{2}-2$ ' and $\mathrm{CH}_{2}-$ 6"), 2.42 (t, $J=6.8 \mathrm{~Hz}, 2 \mathrm{H}, \mathrm{CH}_{2}-2$ '); EI-MS $m / z, 343$ $[\mathrm{M}]^{+}, \quad 207 \quad\left[\mathrm{C}_{11} \mathrm{H}_{15} \mathrm{~N}_{2} \mathrm{O}_{2}\right]^{+}, \quad 165 \quad\left[\mathrm{C}_{9} \mathrm{H}_{11} \mathrm{NO}_{2}\right]^{*+}, \quad 163$ $\left[\mathrm{C}_{9} \mathrm{H}_{9} \mathrm{NO}_{2}\right]^{++}, 95\left[\mathrm{C}_{5} \mathrm{H}_{3} \mathrm{O}_{2}\right]^{+}, 94\left[\mathrm{C}_{6} \mathrm{H}_{5} \mathrm{O}\right]^{+}, 93\left[\mathrm{C}_{5} \mathrm{HO}_{2}\right]^{+}$. Anal. Calc. for $\mathrm{C}_{18} \mathrm{H}_{21} \mathrm{~N}_{3} \mathrm{O}_{4}$ (343.15): $\mathrm{C}, 62.96 ; \mathrm{H}, 6.16$; N, 12.24. Found: C, 62.84; H, 6.25; N, 12.37 . 
<smiles>CCCCNC(=O)Oc1c(Br)cc(Br)cc1OC(=O)NCCCNC(=O)Oc1ccccc1C(=O)N1CCN(CCNC(=O)Oc2ccccc2)CC1</smiles>

Scheme 1. Outline for the synthesis of different carbamate derivatives bearing 2-furoyl-1-piperazine. Reagents and conditions: (I) $10 \%$ aq. $\mathrm{Na}_{2} \mathrm{CO}_{3}$

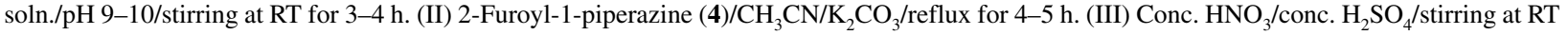
for 3-4 h. (IV) $\mathrm{Br}_{2} / \mathrm{CH}_{3} \mathrm{COOH} /$ stirring at RT for 3-4 h.

\section{5. 2. 2,4,6-Trinitrophenyl 2-[4-(2-furoyl)- 1-piperazinyl]ethylcarbamate (7)}

Sticky brown liquid: 82\%; Mol. F.: $\mathrm{C}_{18} \mathrm{H}_{18} \mathrm{~N}_{6} \mathrm{O}_{10}$; Mol. Mass.: $478 \mathrm{~g} / \mathrm{mol}$; IR $\left(\mathrm{KBr}, \mathrm{cm}^{-1}\right) v_{\max }: 3406(\mathrm{~N}-\mathrm{H}), 3086$ (Ar C-H), $2882(\mathrm{R} \mathrm{C}-\mathrm{H}), 1657(\mathrm{C}=\mathrm{O}), 1582(\mathrm{Ar} \mathrm{C}=\mathrm{C})$, $1490(\mathrm{~N}=\mathrm{O}), 1197(\mathrm{C}-\mathrm{O}-\mathrm{C}), 1110(\mathrm{C}-\mathrm{N}-\mathrm{C}), 848(\mathrm{C}-\mathrm{N})$; ${ }^{1} \mathrm{H}-\mathrm{NMR}\left(500 \mathrm{MHz}, \mathrm{CDCl}_{3}, \mathrm{ppm}\right): \delta 8.15$ (s, $2 \mathrm{H}, \mathrm{H}-3$ and H-5), 7.49 (brs, 1H, H-5"'), 6.99 (d, $J=4.1 \mathrm{~Hz}, 1 \mathrm{H}, \mathrm{H}-3$ "'), 6.49 (dd, $J=1.9,3.2 \mathrm{~Hz}, 1 \mathrm{H}, \mathrm{H}-4$ "'), 5.19 (s, $1 \mathrm{H}, \mathrm{NH}), 3.84$ (brs, $4 \mathrm{H}, \mathrm{CH}_{2}-3$ " and $\mathrm{CH}_{2}-5$ "), 3.39 (t, $J=6.2 \mathrm{~Hz}, 2 \mathrm{H}$, $\mathrm{CH}_{2}-1$ '), 2.56 (brt, $J=6.0 \mathrm{~Hz}, 4 \mathrm{H}, \mathrm{CH}_{2}-2$ " and $\mathrm{CH}_{2}-6$ "), $2.42\left(\mathrm{t}, J=6.8 \mathrm{~Hz}, 2 \mathrm{H}, \mathrm{CH}_{2}-2^{\prime}\right)$; EI-MS $m / z 478[\mathrm{M}]^{+}, 300$ $\left[\mathrm{C}_{9} \mathrm{H}_{8} \mathrm{~N}_{4} \mathrm{O}_{8}\right]^{]^{+}}, 298\left[\mathrm{C}_{9} \mathrm{H}_{6} \mathrm{~N}_{4} \mathrm{O}_{8}\right]^{++}, 254\left[\mathrm{C}_{9} \mathrm{H}_{6} \mathrm{~N}_{3} \mathrm{O}_{6}\right]^{+}, 229$

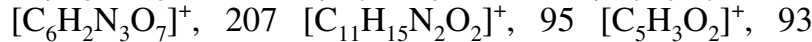
$\left[\mathrm{C}_{5} \mathrm{HO}_{2}\right]^{+}$. Anal. Calc. for $\mathrm{C}_{18} \mathrm{H}_{18} \mathrm{~N}_{6} \mathrm{O}_{10}$ (478.11): C, 45.19; H, 3.79; N, 17.57. Found: C, 45.26; H, 3.85; N, 17.66.

\section{5. 3. 2,4,6-Tribromophenyl 2-[4-(2-furoyl)-1 -piperazinyl]ethylcarbamate (9)}

Sticky brown liquid; Yield: 85\%; Mol. F.: $\mathrm{C}_{18} \mathrm{H}_{18} \mathrm{Br}_{3} \mathrm{~N}_{3} \mathrm{O}_{4}$; Mol. Mass.: $577 \mathrm{~g} / \mathrm{mol}$; IR $\left(\mathrm{KBr}, \mathrm{cm}^{-1}\right)$ $v_{\max }: 3406(\mathrm{~N}-\mathrm{H}), 3086(\mathrm{Ar} \mathrm{C}-\mathrm{H}), 2882(\mathrm{R} \mathrm{C}-\mathrm{H}), 1657$ $(\mathrm{C}=\mathrm{O}), 1582(\mathrm{Ar} \mathrm{C}=\mathrm{C}), 1491(\mathrm{~N}=\mathrm{O}), 1197(\mathrm{C}-\mathrm{O}-\mathrm{C}), 1110$ (C-N-C), $853(\mathrm{C}-\mathrm{N}), 545$ (C-Br); ${ }^{1} \mathrm{H}-\mathrm{NMR}(500 \mathrm{MHz}$, $\mathrm{CDCl}_{3}, \mathrm{ppm}$ ): $\delta 7.75$ (s, 2H, H-3 and H-5), 7.47 (brs, $1 \mathrm{H}$, H-5"'), 7.02 (d, $J=4.1 \mathrm{~Hz}, 1 \mathrm{H}, \mathrm{H}-3$ '”), 6.47 (dd, $J=1.9$, $3.3 \mathrm{~Hz}, 1 \mathrm{H}, \mathrm{H}-4$ "”), 5.18 (s, $1 \mathrm{H}, \mathrm{NH}), 3.83$ (brs, 4H, $\mathrm{CH}_{2}-3$ " and $\mathrm{CH}_{2}-5$ "), $3.36\left(\mathrm{t}, J=6.1 \mathrm{~Hz}, 2 \mathrm{H}, \mathrm{CH}_{2}-1\right.$ '), 2.58 (brt, $J=6.1 \mathrm{~Hz}, 4 \mathrm{H}, \mathrm{CH}_{2}-2$ " and $\mathrm{CH}_{2}-6$ "), 2.45 (t, $J=6.8$ $\left.\mathrm{Hz}, \quad 2 \mathrm{H}, \quad \mathrm{CH}_{2}-2^{\prime}\right) ; \quad$ EI-MS $\mathrm{m} / z \quad 577 \quad[\mathrm{M}]^{+}, \quad 399$ $\left[\mathrm{C}_{9} \mathrm{H}_{8} \mathrm{Br}_{3} \mathrm{NO}_{2}\right]^{\circ+}, 397\left[\mathrm{C}_{8} \mathrm{H}_{6} \mathrm{Br}_{3} \mathrm{NO}_{2}\right]^{\circ+}, 318\left[\mathrm{C}_{9} \mathrm{H}_{8} \mathrm{Br}_{2} \mathrm{NO}_{2}\right]^{+}$, $327\left[\mathrm{C}_{6} \mathrm{H}_{2} \mathrm{Br}_{3} \mathrm{O}\right]^{+}, 207\left[\mathrm{C}_{11} \mathrm{H}_{15} \mathrm{~N}_{2} \mathrm{O}_{2}\right]^{+}, 95\left[\mathrm{C}_{5} \mathrm{H}_{3} \mathrm{O}_{2}\right]^{+}, 93$ $\left[\mathrm{C}_{5} \mathrm{HO}_{2}\right]^{+}$. Anal. Calc. for $\mathrm{C}_{18} \mathrm{H}_{18} \mathrm{Br}_{3} \mathrm{~N}_{3} \mathrm{O}_{4}$ (576.88): C, 37.27; H, 3.13; N, 7.24. Found: C, 37.34; H, 3.21; N, 7.33.

\section{5. 4. Phenyl 3-[4-(2-furoyl)-1-piperazinyl] propylcarbamate (12)}

Sticky brown liquid; Yield: 87\%; Mol. F.: $\mathrm{C}_{19} \mathrm{H}_{23} \mathrm{~N}_{3} \mathrm{O}_{4}$; Mol. Mass.: $357 \mathrm{~g} / \mathrm{mol}$; IR $\left(\mathrm{KBr}, \mathrm{cm}^{-1}\right) v_{\text {max }}$ : $3406(\mathrm{~N}-\mathrm{H}), 3086(\mathrm{Ar} \mathrm{C}-\mathrm{H}), 2882(\mathrm{R} \mathrm{C}-\mathrm{H}), 1657(\mathrm{C}=\mathrm{O})$, $1582(\mathrm{Ar} \mathrm{C}=\mathrm{C}), 1496(\mathrm{~N}=\mathrm{O}), 1197(\mathrm{C}-\mathrm{O}-\mathrm{C}), 1110$ $(\mathrm{C}-\mathrm{N}-\mathrm{C}), 850(\mathrm{C}-\mathrm{N}) ;{ }^{1} \mathrm{H}-\mathrm{NMR}\left(500 \mathrm{MHz}, \mathrm{CDCl}_{3}, \mathrm{ppm}\right)$ : $\delta 7.49$ (brs, $1 \mathrm{H}, \mathrm{H}-5$ "'), 7.42 (brt, $J=7.1 \mathrm{~Hz}, 2 \mathrm{H}, \mathrm{H}-3$ and 
H-5), 7.16 (brt, $J=7.4 \mathrm{~Hz}, 1 \mathrm{H}, \mathrm{H}-4$ ), 7.09 (brd, $J=7.8$ $\mathrm{Hz}, 2 \mathrm{H}, \mathrm{H}-2$ and H-6), 7.05 (d, $J=4.0 \mathrm{~Hz}, 1 \mathrm{H}, \mathrm{H}-3$ "' '), 6.48 (dd, $J=1.9,4.0 \mathrm{~Hz}, 1 \mathrm{H}, \mathrm{H}-4$ "'), 5.15 (s, $1 \mathrm{H}, \mathrm{NH}$ ), 4.10 (t, $J=6.7 \mathrm{~Hz}, 2 \mathrm{H}, \mathrm{CH}_{2}-1$ '), 3.90 (brs, 4H, $\mathrm{CH}_{2}-3$ " and $\mathrm{CH}_{2}-5$ "), 3.64-3.56 (m, 2H, $\mathrm{CH}_{2}-3$ '), 3.46 (brs, $4 \mathrm{H}$, $\mathrm{CH}_{2}-2$ " and $\mathrm{CH}_{2}-6$ "), 2.19 (quintet, $J=6.7 \mathrm{~Hz}, 2 \mathrm{H}$, $\mathrm{CH}_{2} 2^{\prime}$ ); EI-MS $m / z 357[\mathrm{M}]^{+}, 221\left[\mathrm{C}_{12} \mathrm{H}_{17} \mathrm{~N}_{2} \mathrm{O}_{2}\right]^{+}, 179$ $\left[\mathrm{C}_{10} \mathrm{H}_{13} \mathrm{NO}_{2}\right]^{++}, 177\left[\mathrm{C}_{10} \mathrm{H}_{11} \mathrm{NO}_{2}\right]^{*+}, 95\left[\mathrm{C}_{5} \mathrm{H}_{3} \mathrm{O}_{2}\right]^{+}, 93$ $\left[\mathrm{C}_{6} \mathrm{H}_{5} \mathrm{O}\right]^{+}, 93\left[\mathrm{C}_{5} \mathrm{HO}_{2}\right]^{+}$. Anal. Calc. for $\mathrm{C}_{19} \mathrm{H}_{23} \mathrm{~N}_{3} \mathrm{O}_{4}$ (357.17): C, 63.85; H, 6.49; N, 11.76. Found: C, 63.92; H, $6.56 ; \mathrm{N}, 11.82$.

\section{5. 5. 2,4,6-Trinitrophenyl 3-[4-(2-furoyl)- 1-piperazinyl]propylcarbamate (14)}

Sticky brown liquid; Yield: 86\%; Mol. F.: $\mathrm{C}_{19} \mathrm{H}_{20} \mathrm{~N}_{6} \mathrm{O}_{10}$; Mol. Mass.: $492 \mathrm{~g} / \mathrm{mol}$; IR $\left(\mathrm{KBr}, \mathrm{cm}^{-1}\right) v_{\text {max }}$ : $3406(\mathrm{~N}-\mathrm{H}), 3086(\mathrm{Ar} \mathrm{C}-\mathrm{H}), 2882(\mathrm{R} \mathrm{C}-\mathrm{H}), 1657(\mathrm{C}=\mathrm{O})$, $1582(\mathrm{Ar} \mathrm{C}=\mathrm{C}), 1492(\mathrm{~N}=\mathrm{O}), 1197(\mathrm{C}-\mathrm{O}-\mathrm{C}), 1110$ $(\mathrm{C}-\mathrm{N}-\mathrm{C}), 855(\mathrm{C}-\mathrm{N}) ;{ }^{1} \mathrm{H}-\mathrm{NMR}\left(500 \mathrm{MHz}, \mathrm{CDCl}_{3}, \mathrm{ppm}\right)$ : $\delta 7.96$ (s, 2H, H-3 and H-5), 7.48 (brs, $1 \mathrm{H}, \mathrm{H}-5$ '”), 7.02 (d, $J=4.0 \mathrm{~Hz}, 1 \mathrm{H}, \mathrm{H}-3$ '"'), 6.46 (dd, $J=2.0,4.0 \mathrm{~Hz}, 1 \mathrm{H}$, H-4"”), 5.16 (s, 1H, NH), 4.10 (t, $J=6.7 \mathrm{~Hz}, 2 \mathrm{H}, \mathrm{CH}_{2}-1$ '), 3.95 (brs, $4 \mathrm{H}, \mathrm{CH}_{2}-3$ " and $\mathrm{CH}_{2}-5$ "), 3.60-3.57 (m, $2 \mathrm{H}$, $\mathrm{CH}_{2}-3$ '), 3.48 (brs, $4 \mathrm{H}, \mathrm{CH}_{2}-2$ " and $\mathrm{CH}_{2}-6$ "), 2.14 (quintet, $J=6.8 \mathrm{~Hz}, 2 \mathrm{H}, \mathrm{CH}_{2} 2^{\prime}$ ); EI-MS $m / 2,492[\mathrm{M}]^{+}, 314$ $\left[\mathrm{C}_{10} \mathrm{H}_{10} \mathrm{~N}_{4} \mathrm{O}_{8}\right]^{0+}, 312\left[\mathrm{C}_{10} \mathrm{H}_{8} \mathrm{~N}_{4} \mathrm{O}_{8}\right]^{++}, 266\left[\mathrm{C}_{10} \mathrm{H}_{8} \mathrm{~N}_{3} \mathrm{O}_{6}\right]^{+}$, $228\left[\mathrm{C}_{6} \mathrm{H}_{2} \mathrm{~N}_{3} \mathrm{O}_{7}\right]^{+}, 221\left[\mathrm{C}_{12} \mathrm{H}_{17} \mathrm{~N}_{2} \mathrm{O}_{2}\right]^{+}, 95\left[\mathrm{C}_{5} \mathrm{H}_{3} \mathrm{O}_{2}\right]^{+}, 93$ $\left[\mathrm{C}_{5} \mathrm{HO}_{2}\right]^{+}$. Anal. Calc. for $\mathrm{C}_{19} \mathrm{H}_{20} \mathrm{~N}_{6} \mathrm{O}_{10}$ (492.12): C, 46.35; H, 4.09; N, 17.07. Found: C, 46.44; H, 4.17; N, 17.19.

\section{5. 6. 2,4,6-Tribromophenyl 3-[4-(2-furoyl)-1 -piperazinyl]propylcarbamate (16)}

Off-white amorphous solid; Yield: 90\%; m.p.: 80-92 ${ }^{\circ} \mathrm{C}$; Mol. F.: $\mathrm{C}_{19} \mathrm{H}_{20} \mathrm{Br}_{3} \mathrm{~N}_{3} \mathrm{O}_{4}$; Mol. Mass.: 591 $\mathrm{g} / \mathrm{mol}$; IR $\left(\mathrm{KBr}, \mathrm{cm}^{-1}\right) v_{\max }: 3406(\mathrm{~N}-\mathrm{H}), 3086(\mathrm{Ar} \mathrm{C}-\mathrm{H})$, $2882(\mathrm{R} \mathrm{C}-\mathrm{H}), 1657(\mathrm{C}=\mathrm{O}), 1582(\mathrm{Ar} \mathrm{C}=\mathrm{C}), 1497(\mathrm{~N}=\mathrm{O})$, 1197 (C-O-C), $1110(\mathrm{C}-\mathrm{N}-\mathrm{C}), 847(\mathrm{C}-\mathrm{N}), 548(\mathrm{C}-\mathrm{Br})$; ${ }^{1} \mathrm{H}-\mathrm{NMR}\left(500 \mathrm{MHz}, \mathrm{CDCl}_{3}, \mathrm{ppm}\right): \delta 7.67$ (s, 2H, H-3 and H-5), 7.49 (brs, 1H, H-5"'), 7.04 (d, $J=4.1 \mathrm{~Hz}, 1 \mathrm{H}$, H-3"”), 6.49 (dd, $J=2.0,4.0 \mathrm{~Hz}, 1 \mathrm{H}, \mathrm{H}-4$ "”), 5.19 (brs, $1 \mathrm{H}, \mathrm{NH}), 4.12\left(\mathrm{t}, J=6.6 \mathrm{~Hz}, 2 \mathrm{H}, \mathrm{CH}_{2}-1^{\prime}\right), 3.94$ (brs, $4 \mathrm{H}$, $\mathrm{CH}_{2}-3$ " and $\mathrm{CH}_{2}-5$ "), 3.61-3.57 (m, $2 \mathrm{H}, \mathrm{CH}_{2}-3$ '), 3.47 (brs, $4 \mathrm{H}, \mathrm{CH}_{2}-2$ " and $\mathrm{CH}_{2}-6$ "), 2.10 (quintet, $J=6.8 \mathrm{~Hz}$, $2 \mathrm{H}, \mathrm{CH}_{2}-2^{\prime}$ ); EI-MS $m / z 591[\mathrm{M}]^{+}, 413\left[\mathrm{C}_{10} \mathrm{H}_{10} \mathrm{Br}_{3} \mathrm{NO}_{2}\right]^{0+}$, $411 \quad\left[\mathrm{C}_{10} \mathrm{H}_{8} \mathrm{Br}_{3} \mathrm{NO}_{2}\right]^{0+}, \quad 332 \quad\left[\mathrm{C}_{10} \mathrm{H}_{10} \mathrm{Br}_{2} \mathrm{NO}_{2}\right]^{+}, \quad 328$ $\left[\mathrm{C}_{6} \mathrm{H}_{3} \mathrm{Br}_{3} \mathrm{O}\right]^{++}, 221\left[\mathrm{C}_{12} \mathrm{H}_{17} \mathrm{~N}_{2} \mathrm{O}_{2}\right]^{+}, 95\left[\mathrm{C}_{5} \mathrm{H}_{3} \mathrm{O}_{2}\right]^{+}, 93$ $\left[\mathrm{C}_{5} \mathrm{HO}_{2}\right]^{+}$. Anal. Calc. for $\mathrm{C}_{19} \mathrm{H}_{20} \mathrm{Br}_{3} \mathrm{~N}_{3} \mathrm{O}_{4}$ (590.90): C, 38.41; H, 3.39; N, 7.07. Found: C, 38.49; H, 3.44; N, 7.18.

\section{6. Biological Activity Assays (in vitro)}

\section{6. 1. $\alpha$-Glucosidase Assay}

The $\alpha$-glucosidase inhibition activity was performed in accordance with the slightly modified method of Pierre et al. ${ }^{27}$ Total volume of the reaction mixture of $100 \mu \mathrm{L}$ contained $70 \mu \mathrm{L} 50 \mathrm{mM}$ phosphate buffer saline, $\mathrm{pH} 6.8$, $10 \mu \mathrm{L}(0.5 \mathrm{mM})$ test compound, subsequently the addition of $10 \mu \mathrm{L}$ ( 0.057 units) enzyme. The contents were mixed, preincubated for $10 \mathrm{~min}$ at $37{ }^{\circ} \mathrm{C}$ and pre-read at $400 \mathrm{~nm}$. The reaction was initiated by the addition of $10 \mu \mathrm{L}$ of 0.5 $\mathrm{mM}$ substrate ( $p$-nitrophenylglucopyranoside). Acarbose was used as positive control. After $30 \mathrm{~min}$ of incubation at $37^{\circ} \mathrm{C}$, absorbance was measured at $400 \mathrm{~nm}$ using Synergy HT microplate reader. All experiments were carried out in duplicates. The percent inhibition was calculated by the following equation:

$$
\text { Inhibition }(\%)=\frac{\text { Control }- \text { Test }}{\text { Control }} \times 100
$$

$\mathrm{IC}_{50}$ values (concentration at which there is $50 \%$ in enzyme catalyzed reaction) compounds were calculated using EZ-Fit Enzyme Kinetics Software (Perrella Scientific Inc. Amherst, USA).

\section{6. 2. Cholinesterase Inhibition Assay}

The AChE and $\mathrm{BChE}$ inhibition activities were performed according to the method of Ellman et al., with minor modifications. ${ }^{28}$ Total volume of the reaction mixture was $100 \mu \mathrm{L}$. It contained $60 \mu \mathrm{L} \mathrm{Na}_{2} \mathrm{HPO}_{4}$ buffer with concentration of $50 \mathrm{mM}$ and $\mathrm{pH}$ 7.7. Ten $\mu \mathrm{L}$ test compound ( $0.5 \mathrm{mM}$ per well) was added, followed by the addition of $10 \mu \mathrm{L}$ (0.005 unit per well) enzyme. The contents were mixed and pre read at $405 \mathrm{~nm}$. Then contents were pre incubated for 10 mins at $37^{\circ} \mathrm{C}$. The reaction was initiated by the addition of $10 \mu \mathrm{L}$ of $0.5 \mathrm{mM}$ per well substrate (acetylthiocholine iodide / butyrylthiocholine iodide), after that the addition of $10 \mu \mathrm{L}$ DTNB $(0.5 \mathrm{mM}$ per well). After 15 mins of incubation at $37^{\circ} \mathrm{C}$ absorbance was measured at $405 \mathrm{~nm}$. All experiments were carried out with their individual controls in triplicate. Eserine $(0.5 \mathrm{mM}$ per well) was used as a positive control. The inhibition (\%) and $\mathrm{IC}_{50}$ were calculated by the same method as described in $\alpha$-glucosidase assay.

\section{6. 3. Antibacterial Activity}

The antibacterial activity was evaluated in sterile 96-wells microplates under aseptic conditions. The method is rooted in the principle that microbial cell number increases as the microbial growth proceeds in a log phase of growth which results in increased absorbance of broth medium. ${ }^{29,30}$ Three gram-negative (Salmonella typhi, Escherichia coli and Pseudomonas aeruginosa) and two gram-positive bacteria (Bacillus subtilis, Staphylococcus aureus) were included in the study. The organisms were maintained on stock culture agar medium. The test samples with suitable solvents and dilutions were pipette into wells ( $20 \mu \mathrm{g}$ per well). Overnight maintained fresh bacte- 
rial culture after suitable dilution with fresh nutrient broth was poured into wells $(180 \mu \mathrm{L})$. The initial absorbance of the culture was strictly maintained between $0.12-0.19$ at $540 \mathrm{~nm}$. The total volume in each well was kept to $200 \mu \mathrm{L}$. The incubation was done at $37{ }^{\circ} \mathrm{C}$ for $16-24$ hours with lid on the microplate. The absorbance was measured, before and after incubation and the difference was noted as an index of bacterial growth at $540 \mathrm{~nm}$ by using microplate reader. The percent inhibition was calculated by using the formula:

$$
\text { Inhibition }(\%)=\frac{X-Y}{X} \times 100
$$

where $X$ is absorbance in the control with bacterial culture and $Y$ is absorbance in the test sample. Results are mean of triplicate $(n=3, \pm$ SEM). Ciprofloxacin was used as the standard. Minimum inhibitory concentration (MIC) was measured with suitable dilutions (5-30 $\mu \mathrm{g}$ per well) and results were calculated using EZ-Fit 5 Perrella Scientific Inc. Amherst USA software, and data expressed as MIC.

\section{6. 4. Statistical Analysis}

The results are written as mean \pm SEM after performance in three-folds and statistical analysis by Microsoft Excel 2010. Minimum inhibitory concentration (MIC) was calculated by using different dilutions (ranging 5-30 $\mu \mathrm{g}$ per well) and EZFit Perrella Scientific Inc. Amherst USA software.

\section{6. 5. Hemolytic Activity}

Hemolytic activity was done by a reported method. ${ }^{31,32}$ Bovine blood was obtained from the Department of Clinical Medicine and Surgery, University of Agriculture, Faisalabad, Pakistan. After centrifugation, separation and washing, the \% RBCs lysis was computed by noting the absorbance.

\section{6. 6. Molecular Docking Methodology}

For the prediction of bioactive conformations, various synthesized compounds were docked into the active pockets of the following chosen proteins/enzymes by using the default parameters of MOE-Dock program. Earlier to dock the ligands into enzyme molecules, Builder of MOE 2009-10 was implemented to sketch the structures of synthesized compounds. Energy minimization was carried out up to 0.05 gradients by using MMFF94x force field through the default parameter of the MOE energy minimization algorithm. Then the energy minimized molecules were saved in the mdb file format as an input database for molecular docking in the subsequent step.

The enzyme molecules of $\alpha$-glucosidase (PDB ID code: $3 \mathrm{NO} 4$ ), acetylcholinesterase (PDB ID code: 1GQR) and butyrylcholinesterase (PDB ID code: 1POP) were retrieved from Protein Data Bank having the possible resolutions of $2.02 \AA, 1.69 \AA$ and $2.30 \AA$ respectively. Then all the water molecules were extracted from the receptor enzymes and 3D protonation was carried out through Protonate 3D Option. Energies of protein molecules were minimized by using the default parameters of MOE 2009-10 energy minimization algorithm (gradient: 0.05, Force Field: MMFF94X). Then all the ligands were docked into the binding pockets (selective residues/amino acids) of the above enzymes using default parameters of MOE-Dock Program. To increase the validity of docking protocol, redocking was also applied. ${ }^{33}$ LigPlot which is implemented in MOE (Molecular Operating Environment) was used to determine the interactions between enzymes and ligands.

\section{Conclusion}

The structures of synthesized unique carbamate derivatives bearing 2-furoyl-1-piperazine moieties were elucidated by spectral techniques. All the derivatives showed decent inhibitory potential against acetylcholinestrase enzyme and almost all the derivatives were active against the studied strains of Gram-positive and Gram-negative bacteria. The results of cytotoxicity studies were used to evaluate their cytotoxicity profile as these molecules exhibited modest toxicity. Hence, these molecules may be considered as suitable therapeutic entrants for the drug designing programs leading to some life saving medication.

\section{Acknowledgement}

The authors are highly thankful to Higher Education Commission (HEC) of Pakistan for providing financial support in this study.

\section{References}

1. R. Kharb, P. C. Sharma, A. Bhandari, M. Shaharyar, Der. Pharmacia. Lett. 2012, 4, 652-657.

2. J. Faist, W. Seebacher, R. Saf, R. Brun, M. Kaiser, R. Weis, Eur. J. Med. Chem. 2012, 47, 510-519. https://doi.org/10.1016/j.ejmech.2011.11.022

3. K. Kulig, J. Sapa, D. Maciag, B. Filipek, B. Malawska, Arch. Pharm. 2007, 340, 466-475. https://doi.org/10.1002/ardp.200700039

4. A. Pietrzycka, M. Stepniewski, A. M. Waszkielewicz, H. Marona, Acta Pol. Pharm. 2006, 63, 19-24.

5. S. Bartoschek, J. A. Vorholt, R. K. Thauer, B. H. Geierstanger, C. Griesinger, Eur. J. Biochem. 2001, 267, 3130-3138. https://doi.org/10.1046/j.1432-1327.2000.01331.x

6. R. L. Metcalf: "Insect Control” in Ullmann's Encyclopedia of Industrial Chemistry, Wiley-VCH, Weinheim, 2002. 
7. S. Badreshia, Am. J. Contact. Dermat. 2002, 13, 77-79.

8. J. F. Holland, H. Hosley, C. Scharlau, Blood 1966, 27, 328342.

9. A. J. Hirsh, S. Y. Yao, J. D. Young, C. I. Cheeseman, Gastroenterology 1997, 113, 205-211. https://doi.org/10.1016/S0016-5085(97)70096-9

10. S. Chiba, Biosci., Biotechnol. Biochem. 1997, 61, 1233 1239. https://doi.org/10.1271/bbb.61.1233

11. A. D., Baron, Diabetes Res. Clin. Pract. 1998, 40, 51-55.

12. H. E. Lebovitz, Clin. North Am. 1997, 26, 539-551.

13. M. Cygler, J. D. Schrag, J. Sussman, L. M. Harel, I. Silman, M. K. Gentry, Protein Sci. 1993, 2, 366-382. https://doi.org/10.1002/pro.5560020309

14. V. Tougu, Curr. Med. Chem. 2001, 1, 155-170.

15. P. Substance In: Handbook of experimental pharmacology. Ed. G. Bertaccini, Berlin, Springer Verlag, 1982, 59/II, 85105.

16. S. Gauthier, Drug \& Aging 2001, 18, 853-862. https://doi.org/10.2165/00002512-200118110-00006

17. World Health Organization. Typhoid vaccines: WHO position paper. Wkly. Epidemiol. Rec. 2000, 75, 257-264.

18. J. A. Crump, S. P. Luby, E. D. Minta, Bull. WHO. 2004, 82, 346-353.

19. A. A. Bahiru, S. A. Emire, A. K. Ayele, Acad. J. Microbiol. Res. 2013, 1, 1-10.

20. M. Rosenfeld, J. Emerson, F. Accurso, D. Armstrong, R. Castile, K. Grimwood, P. Hiatt, Pediatr. Pulmonol. 1999, 28, 321-328.

https://doi.org/10.1002/(SICI)1099-0496(199911)28:5<321: :AID-PPUL3>3.0.CO;2-V

21. V. R. Barbe, S. P. Cruveiller, F. Kunst, P. Lenoble, G. Meurice, A. Sekowska, D. Vallenet, T. Wang, I. Moszer, C. M. digue, A. Danchin, Microbiology 2009, 155, 1758-1775. https://doi.org/10.1099/mic.0.027839-0
22. F. D. Lowy, Trends Microbiol. 1998, 8, 341-344. https://doi.org/10.1016/S0966-842X(00)01803-5

23. M. A. Abbasi, A. Hafeez, Aziz-ur-Rehman, K. M. Khan, M. Ashraf, S. A. Ejaz, Asian J. Pharma. Hea. Sci. 2012, 2, 461-466.

24. M. A. Abbasi, A. Sonia, Aziz-ur-Rehman, K. M. Khan, M. Ashraf, I. Afzal, N. Ambreen, M. Shahid, M. Abbas, J. Chem. Soc. Pak. 2013, 35, 385-390.

25. Aziz-ur-Rehman, S. Naeem, M. A. Abbasi, S. Rasool, K. Nafeesa, I. Ahmad, S. Afzal, Sci. Iran. 2015, 22, 2241-2248. https://doi.org/10.12966/jsmr.06.02.2014

26. P. S. Nayak, B. Narayana, B. K. Sarojini, J. Fernandes, Akshatha, J. Single Mol. Res. 2014, 2, 20-26.

27. P. Chapdelaine, R. R. Tremblay, J. Y. Dube, Clin. Chem. 1978, 24, 208-211.

28. G. L. Ellman, K. D. Courtney, V. Andres, R. M. Featherstone, Bio. Pharm. 1961, 7, 88-95. https://doi.org/10.1016/0006-2952(61)90145-9

29. M. Kaspady, V. K. Narayanaswamy, M. Raju, G. K. Rao, Lett. Drug Des. Discov. 2009, 6, 21-28. https://doi.org/10.2174/157018009787158481

30. C.-R. Yang, Y. Zang, M. R. Jacob, S. I. Khan, Y.-J. Zhang, X.C. Li, Antimicrob. Agents. Chemother. 2006, 50, 1710-1714. https://doi.org/10.1128/AAC.50.5.1710-1714.2006

31. P. Sharma, J. D. Sharma, J. Ethnopharmacol. 2001, 74, 239-243. https://doi.org/10.1016/S0378-8741(00)00370-6

32. W. A. Powell, C. M. Catranis, C. A. Maynard, Lett. Appl. Microbiol. 2000, 31, 163-168. https://doi.org/10.1046/j.1365-2672.2000.00782.x

33. M. J. Bostro, J. R. Greenwood, J. Gottfries, Mol. Graph. Model. 2003, 21, 449-462. https://doi.org/10.1016/S1093-3263(02)00204-8

\section{Povzetek}

Namen predstavljenega raziskovalnega dela je bila sinteza različnih biološko aktivnih karbamatnih derivatov, ki bi vsebovali 2-furoil-1-piperazinski fragment in bi bili le malo strupeni. Sintezo smo izvedli kot večstopenjsko sekvenco. Strukturno potrditev pripravljenih spojin smo izvedli s pomočjo EI-MS, IR in ${ }^{1} \mathrm{H}-\mathrm{NMR}$ spektroskopskih metod. Za pripravljene spojine smo določili tudi sposobnost inhibicije encimov in njihovo antibakterijsko delovanje. Da bi ugotovili potencialno uporabnost dobljenih spojin kot terapevtskih učinkovin, smo določili tudi njihovo citotoksičnost. Vse spojine so se izkazale kot aktivne proti acetilholinesterazi; spojini $\mathbf{1 2}$ in $\mathbf{1 4}$ sta izkazovali še posebej dobro inhibitorno aktivnost v primerjavi z referenčnim standardom ezerinom. Skoraj vse spojine so se pokazale kot učinkovite tudi proti Grampozitivnim in Gram-negativnim bakterijskim sevom. 